\title{
Multicriteria Decision Aid to support Multilateral Environmental Agreements in assessing international forestry projects
}

\author{
Rocío Dánica Cóndor • Antonino Scarelli • Riccardo Valentini
}

Accepted: 10 March 2010/Published online: 10 April 2010

(C) The Author(s) 2010. This article is published with open access at Springerlink.com

\begin{abstract}
The three Rio Conventions-the United Nations Framework Convention on Climate Change, the Convention on Biological Diversity, and the United Nations Convention to Combat Desertification-face the challenge to create synergies at different levels. The objective of this article is to describe how we have assessed synergies between the Rio Conventions at the project level in the forest sector. Since the complexity of the decision problem is high, we adopted the Multicriteria Decision Aid approach, which can provide a broad insight into the decision problem and find a compromise solution to a problem with multidimensional and conflicting criteria including social, economic and environmental features. The ELECTRE TRI model was used for assessing synergies at the project level, and has been a useful tool to quantify the performance of afforestation and reforestation projects into three categories (synergistic, reasonably synergistic, and not synergistic). For the first time, afforestation and reforestation projects have been assessed in a comprehensive way through decision criteria that reflect global and local interests using a non-compensatory multicriteria method.
\end{abstract}

Keywords Forestry projects · Multiple criteria - Multilateral environmental agreements · Rio conventions
Abbreviations
AHTEG Ad hoc technical expert group
$\mathrm{A} / \mathrm{R} \quad$ Afforestation/Reforestation
CBD Convention on Biological Diversity
CDM Clean Development Mechanism
DM Decision maker

R. D. Cóndor $(\bowtie) \cdot R$. Valentini

Dipartimento di Scienze dell'Ambiente Forestale e delle sue Risorse (DISAFRI),

Università degli Studi della Tuscia, Via S. Camillo de Lellis snc, 01100 Viterbo, Italy

e-mail: rociocondor@libero.it

A. Scarelli

Dipartimento di Ecologia ed Sviluppo Economico Sostenibile (DECOS),

Università degli Studi della Tuscia, Via S. G. Decollato 1, 01100 Viterbo, Italy 


$\begin{array}{ll}\text { GEF } & \text { Global Environmental Facility } \\ \text { IAS } & \text { Institute of Advanced Studies } \\ \text { JLG } & \text { Joint Liaison Group } \\ \text { MA } & \text { Millennium ecosystem assessment } \\ \text { MAUT } & \text { Multiple attribute utility theory } \\ \text { MCDA } & \text { Multicriteria Decision Aid } \\ \text { MEAs } & \text { Multilateral Environmental Agreements } \\ \text { NCSA } & \text { National capacity self assessment } \\ \text { PDDs } & \text { Project design documents } \\ \text { UNEP } & \text { United Nations Environmental Programme } \\ \text { UNFCCC } & \text { United Nations Framework Convention on Climate Change } \\ \text { UNCCD } & \text { United Nations Convention to Combat Desertification } \\ \text { UNU } & \text { United Nations University }\end{array}$

\section{Introduction}

Multilateral environmental agreements (MEAs) tackle transboundary and environmental problems caused by international economic activities. At the United Nations Conference on Environment and Development (the 'Earth Summit') in 1992 in Rio de Janeiro, three important MEAs were agreed upon, also known as the 'Rio Conventions'. These conventions are the United Nations Framework Convention on Climate Change (UNFCCC), the Convention on Biological Diversity (CBD), and the United Nations Convention to Combat Desertification (UNCCD). The common objective of these Conventions is to achieve sustainable development. Nevertheless, they have different objectives such as the stabilization of greenhouse gas concentrations in the atmosphere (UNFCCC), the conservation, sustainable use and the fair and equitable share of the benefits arising from genetic resources (CBD), and combating desertification and land degradation (UNCCD). Since the mid-1990s, synergies among MEAs have increasingly drawn attention at the international level, with a focus on creating and improving cooperation between different agreements. In 1999, the United Nations University (UNU) developed the Inter-linkages Initiative through a 3-year program aimed at identifying practical ways to promote a more integrated and comprehensive approach to the negotiation, ratification, and implementation of MEAs (Velasquez et al. 2002). Up to now, synergies have been pursued at the global (e.g. creation of the Joint Liaison Group, $\mathrm{JLG}^{1}$ ), regional (e.g. framework for managing transboundary ecosystems; UNU-IAS 2004), and national (e.g. National Capacity Self Assessment project $^{2}$; IUCN 2005) levels. Against this background, the importance of developing methodologies and tools for assessing synergies among the Rio Conventions has been emphasized (IPCC 2002; UNFCCC 2004; UNEP/CBD 2005). Initiatives to evaluate how activities could contribute simultaneously to different objectives (e.g. climate change and

\footnotetext{
1 The JLG the secretariats of the CBD, the UNFCCC and the UNCCD aims to enhance coordination between the three conventions and to explore options for further cooperation.

${ }^{2}$ NCSAs are a way for countries to conduct a thorough self-assessment and analysis of national capacity needs, priorities, and constraints with respect to efforts toward meeting global environmental management objectives. They are financed by the Global Environment Facility (GEF).
} 
biodiversity) through a checklist procedure have been proposed (GEF 2004; UBA 2004a). However, in-depth studies on how to deal with the assessment of synergies are lacking.

The UNFCCC, CBD, and UNCCD, in the JLG context, have identified forests and forest ecosystems as a common topic, enabling conventions to participate and benefit from the exchanges and findings (UNFCCC 2002; UNCCD/CBD 2004; UNEP/CBD 2004; UNEP/ CBD 2007). The multiple characteristics of the forest sector provide an opportunity to implement the Rio Convention objectives in a synergistic fashion. In particular, different authors highlight the central role of forestry projects at different levels (Klooster and Masera 2000; Masera et al. 2001; Caparrós and Jacquemont 2003; Nelson and de Jong 2003; Corbera et al. 2007). This implies that projects could be implemented in different regions through specific interventions. For instance, natural resource management projects in certain parts of Europe and Central Asia may largely involve arable soils conservation and water salinity management for irrigation, or in Latin America and the Caribbean projects may involve preserving areas of high endemism in protected areas (World Bank 2005). For this study, we have chosen to assess synergies at the project level.

In order to carry out a multidimensional assessment of forestry projects, the Multicriteria Decision Aid (MCDA) approach was adopted. The aim of the MCDA approach is to give the decision maker (DM) tools that enable solving a decision problem where several points of view need to be considered. Four reference problematics can be analyzed with the MCDA approach: (1) selecting the best alternative/set of alternatives (choice problematic); (2) sorting alternatives into predefined homogenous groups (sorting problematic); (3) constructing a rank-ordering of the alternatives from the best to the worst ones (ranking problematic); and (4) determining the performance without seeking to elaborate any prescription, or recommendation (description problematic). In general, the MCDA literature is focused on the first three problematics.

Decision aiding methods are most of the times based on mathematically explicit multicriteria aggregation procedures (Roy 2005). The common MCDA methods used are (1) the single synthesizing criterion approach (e.g. MAUT, SMART, TOPSIS, MACBETH, AHP); (2) the outranking synthesizing approach (e.g. ELECTRE, MELCHIOR, trichotomic segmentation and PROMETHEE); and (3) the interactive local judgements with trialand-error approach. A review of these approaches is presented in Guitouni and Martel (1998). Vincke (1992) called these three approaches (1) the multi-attribute utility theory methods; (2) the outranking methods; and (3) the interactive methods. However, other methods like rough sets or decision rule approaches can also be applied to MCDA problems.

Since sustainable development is a multidimensional concept, the MCDA approach constitutes a powerful tool that takes into account several-possibly conflicting-concerns, and organizes information to achieve a compromise solution. In this context, the concepts of 'weak' and 'strong' sustainability are relevant in choosing an appropriate multicriteria method (Munda 1997; Martinez-Alier et al. 1998; Rennings and Hohmeyer 1997). Weak sustainability allows substitution between different types of capitals. For instance, in theory further depletion of the ozone layer could be compensated by projects supporting the protection of panda bears (Rennings and Hohmeyer 1997). Strong sustainability is based on the assumption that certain sorts of natural capital are deemed critical and are not readily substitutable by man-made capital (Barbier and Markandya 1990). If one wishes to measure sustainability with sufficient policy relevance, the best available technique is to set 'strong' sustainability constraints (Dietz and Neumayer 2007). Therefore, a fundamental concept in MCDA is the issue of compensation. This concept refers to the existence of trade-offs, i.e. the possibility of offsetting a disadvantage on some 
criteria by a sufficiently large advantage on another criterion (Munda 2005). In general, two kinds of aggregation are found: compensatory in which trade-offs are made and noncompensatory in which non trade-offs are made. Non-compensatory multicriteria methods are quite significant because they operationalize the concept of 'strong' sustainability (Munda 1997, 2005). An example of non-compensatory methods is the ELECTRE family methods.

The objective of this article is to describe how we have assessed synergies among the Rio Conventions at the project level. The assessment was seen as a decision problem. Thus, a decision aiding process concept was applied to organize this study. The outline of the article is as follows: Sect. 2 explains the methodological framework of this research, Sect. 3 describes the results, Sect. 4 presents a discussion, and Sect. 5 reports on the main conclusions.

\section{Methodology}

\subsection{The decision aiding process}

From a practical point of view, the decision aiding process concept is helpful to guide the decision process, encourage reasoning, and review all steps undertaken. The activities of a decision aiding process are a reasoned result of interactions between the researcher/s and the decision maker (DM). For this study, the DM represents the person who is in charge of assessing synergies in forestry projects (in this case, the Head of the Department of Forest Resources and Environment of the Tuscia University in Italy). These activities involve the definition of the (Stamelos and Tsoukiàs 2003; Bouyssou et al. 2006; Tsoukiàs 2007):

- problem situation;

- problem formulation;

- evaluation model; and

- final recommendations.

In identifying the problem situation, one tries to reply to questions such as 'who has a problem?', 'why is this a problem?', and 'who decides on this problem?' From a formal point of view, a representation of the problem situation identifies the set of participants in the decision process and the set of stakes each participant brings to the decision process. Considerable effort has been put into obtaining expert judgments. Experts have been involved directly (through personal interviews) and indirectly (through a questionnaire) in different steps of the process; thus, they have become an important resource for the study. In Fig. 1, we present the problem situation.

A real-world problem identified in the context of MEAs is the lack of methodologies to assess synergies among the Rio Conventions at forestry the project level. The problem formulation reduces the reality of the decision process, in which the DM is involved, to a formal and abstract problem. Consequently, concerns are transformed into formal problems to which a method can be applied (already existing, adapted from an existing one or created ad hoc). From a formal point of view, we defined a potential set of alternatives to be evaluated with the multicriteria method, and the points of view under which the alternatives need to be assessed (decision criteria). For the problem formulation, different problem statements are proposed (as explained before, one can choose, rank, or sort a set of alternatives). We argue that the aim of assessing synergies at the project level could be achieved through sorting projects (problem formulation). To this end, ten project design 


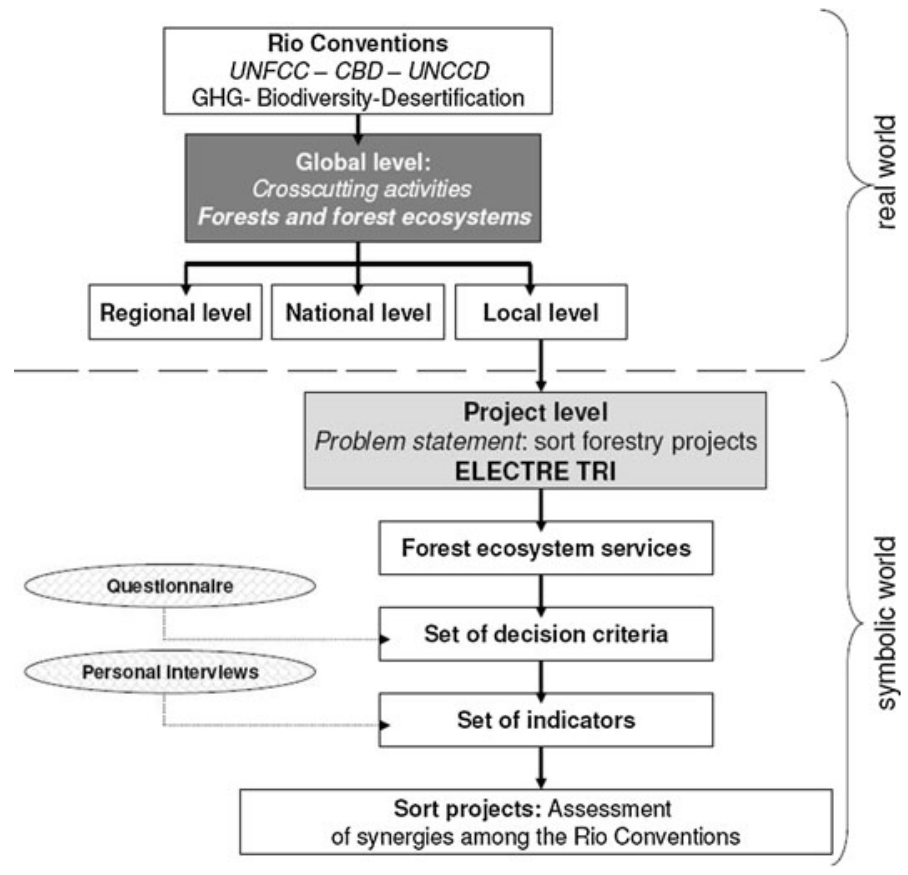

Fig. 1 The representation of the problem situation

documents (PDDs) of afforestation and reforestation (A/R) projects submitted for validation by the end of November 2007 have been selected. PDDs presented information on technical and organizational aspects of $\mathrm{A} / \mathrm{R}$ project activities. They are mandatory documents in the framework of the Kyoto Protocol's Clean Development Mechanism (CDM), which allows developed countries to invest in projects that reduce greenhouse gas emissions in developing countries in order to achieve their Kyoto targets. Table 1 contains information on the projects, including the regions in which they are implemented, type of interventions, products which are obtained, hectares involved in the projects, and participants in the projects. The set of forestry criteria and indicators used for this decision problem are described in the next section. For the evaluation model phase, a formal method to elaborate the solution is required. An outranking approach (the ELECTRE TRI model) has been adopted for this study. This approach seeks to establish the evidence for favouring the alternative that performs the best on the greatest number of criteria, which is very useful in the assessment of synergies among the Rio Conventions. Final recommendations need to translate results obtained from the evaluation model. Therefore, a sensitivity and robustness analysis are suggested prior to making the final recommendations.

For the development of this research, which required knowledge on different topics (multicriteria methods, decision aiding, ecosystem services, forestry projects, sustainable development, project assessment, etc.) 340 references were selected (see Cóndor 2008). Key environmental journals, reports, working papers, and documents from related international organizations were consulted. Moreover, participation in the European Working Group on Multicriteria Decision (EWG-MCDA) and the EURO Working Group on Operational Research in Agriculture and Forestry Management (EWG-ORAFM) enabled contacts with experts and up-to-date information. 
Table 1 Characteristics of the international forestry projects

\begin{tabular}{|c|c|c|c|c|}
\hline Projects & Type of project & Products & $\begin{array}{l}\text { Hectares } \\
\text { (ha) }\end{array}$ & Participants \\
\hline China (FP1) & $\begin{array}{l}\text { Forest rehabilitation } \\
\text { and regeneration }\end{array}$ & Forest products & 4,000 & $\begin{array}{l}\text { Government, private entity, } \\
\text { farmers }\end{array}$ \\
\hline $\begin{array}{l}\text { Moldavia } \\
\text { (FP2) }\end{array}$ & $\begin{array}{l}\text { Forest rehabilitation } \\
\text { and regeneration }\end{array}$ & $\begin{array}{l}\text { Fuel wood, timber, and } \\
\text { non-timber products }\end{array}$ & 20,290 & $\begin{array}{l}\text { State Forest Agency, } \\
\text { Prototype Carbon Fund } \\
\text { (PCF), BioCarbon Fund }\end{array}$ \\
\hline $\begin{array}{c}\text { Albania } \\
\text { (FP3) }\end{array}$ & $\begin{array}{l}\text { Forest rehabilitation } \\
\text { and regeneration }\end{array}$ & $\begin{array}{l}\text { Wood products. Other: } \\
\text { medicinal plant, nuts, and } \\
\text { fruits }\end{array}$ & 5,728 & $\begin{array}{l}\text { Government, local } \\
\text { administration, bank }\end{array}$ \\
\hline $\begin{array}{l}\text { Honduras } \\
\text { (FP4) }\end{array}$ & $\begin{array}{l}\text { Forest rehabilitation } \\
\text { and regeneration/ } \\
\text { agroforestry }\end{array}$ & $\begin{array}{l}\text { Diversity: products from } \\
\text { agroforestry and } \\
\text { commercial forestry }\end{array}$ & 2,600 & $\begin{array}{l}\text { Foundation from the } \\
\text { national park, } \\
\text { environmental funds, } \\
\text { private institution, } \\
\text { individual farmers }\end{array}$ \\
\hline Brazil (FP5) & Industrial plantations & $\begin{array}{l}\text { Wood for energy/supply of } \\
\text { charcoal }\end{array}$ & 11,683 & $\begin{array}{l}\text { Private company and PCF } \\
\text { from the world bank }\end{array}$ \\
\hline China (FP6) & $\begin{array}{l}\text { Forest rehabilitation } \\
\text { and regeneration }\end{array}$ & $\begin{array}{l}\text { Plantations (control soil } \\
\text { and wind erosion), forage } \\
\text { (animal husbandry), and } \\
\text { the intercropped crops } \\
\text { (food outputs) }\end{array}$ & 3,000 & $\begin{array}{l}\text { Private entities, research } \\
\text { institution, national } \\
\text { commission on } \\
\text { desertification, Italian } \\
\text { ministry of environment }\end{array}$ \\
\hline $\begin{array}{l}\text { Ecuador } \\
\text { (FP7) }\end{array}$ & $\begin{array}{l}\text { Forest rehabilitation } \\
\text { and regeneration }\end{array}$ & $\begin{array}{l}\text { Long-term forest } \\
\text { plantation, no harvesting } \\
\text { of wood products } \\
\text { foreseen }\end{array}$ & 523 & $\begin{array}{l}\text { Foundation Maquipucuna, } \\
\text { Ecologic Foundation } \\
\text { Susan Sheppard, Mrs. } \\
\text { Susan Sheppard; Japan } \\
\text { RICOH Ltd. }\end{array}$ \\
\hline $\begin{array}{l}\text { Madagascar } \\
\text { (FP8) }\end{array}$ & $\begin{array}{l}\text { Industrial plantations } \\
\text { (reforestation on } \\
\text { degraded land) }\end{array}$ & $\begin{array}{l}\text { Wood chips for pulp } \\
\text { materials }\end{array}$ & 15,000 & $\begin{array}{l}\text { Local plantation company } \\
\text { established by Oji Paper } \\
\text { Co. Ltd., and other } \\
\text { Japanese private } \\
\text { companies }\end{array}$ \\
\hline $\begin{array}{l}\text { Colombia } \\
\text { (FP9) }\end{array}$ & $\begin{array}{l}\text { Silvopastoral, } \\
\text { agroforestry, and } \\
\text { forest plantations }\end{array}$ & $\begin{array}{l}\text { Silvopastoral, agroforestry, } \\
\text { and forest plantations }\end{array}$ & 8,730 & $\begin{array}{l}\text { Private corporation, many } \\
\text { others: farmer } \\
\text { communities, } \\
\text { municipalities, regional } \\
\text { authority, NGOs, church, } \\
\text { universities }\end{array}$ \\
\hline $\begin{array}{l}\text { Brazil } \\
\text { (FP10) }\end{array}$ & $\begin{array}{l}\text { Industrial plantations } \\
\text { (afforestation/ } \\
\text { reforestation } \\
\text { project) }\end{array}$ & $\begin{array}{l}\text { No products (riparian } \\
\text { areas) }\end{array}$ & 8,094 & Private entity AES Tiete \\
\hline
\end{tabular}

Source: UNFCCC (2007)

\subsection{The ELECTRE TRI model}

The ELECTRE TRI model consists of assigning a set of alternatives evaluated on all criteria to predefined categories (Yu 1992; Roy and Bouyssou 1993; Mousseau and Slowinski 1998; Mousseau et al. 1999, 2000, 2003). For this study, the forestry projects are considered the set of alternatives. The assignment of a project to a specific category results 


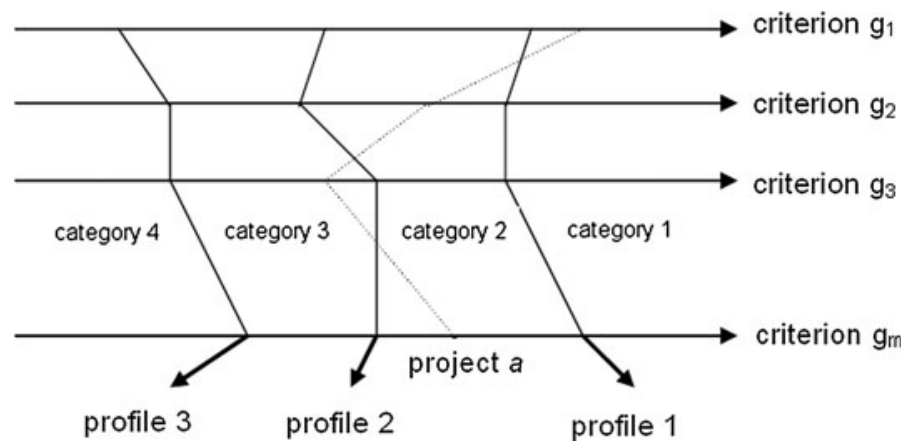

Fig. 2 ELECTRE TRI model representation

from the comparison of its evaluation on all criteria $\left(g_{1}, g_{2} \ldots g_{m}\right)$ with the profiles, which define the limits of the categories. As an example, in Fig. 2, we show an illustration of the ELECTRE TRI model, where three profiles and four categories are defined, and the light line are the evaluation of project $a$. In general, from a set of alternatives, evaluated against quantitative and/or qualitative criteria and from a predetermined set of profiles, the method proposes two different approaches that allow the classification of the alternatives in the right category. Through the pessimistic approach, project $a$ can be assigned to a category when its evaluation on each criterion is at least as good as the lower limit that has been defined on the criterion to be in this category. Then, project $a$ is assigned to the highest category fulfilling this condition. Instead, with the optimistic approach, the project $a$ can be assigned to a category, if it has, on at least one criterion, an evaluation at least as good as the lower limit that has been defined in the criterion to be in this category. Then, project a is assigned to the highest category fulfilling this condition. Siskos (2007) suggests that the pessimistic approach should be used when it is required to apply a conservative policy or when the available resources are limited, while the optimistic approach can be used for problems where the DM wants to give a comparative advantage to certain alternatives with a specific interest. Moreover, another advantage of two assignment procedures is to refuse compensation among the evaluations of alternatives according to the multiple criteria.

For the ELECTRE TRI model, the indifference, preference and veto thresholds, and weights are parameters that need to be defined for each criterion. A further description of the ELECTRE TRI model is provided in Figueira et al. (2005). Recent real-world case studies in which sustainability is assessed with multicriteria methods are also available (Madlener et al. 2009; Kowalski et al. 2009).

\subsection{Decision criteria}

Criteria represent the axes along which the different actors of the decision process justify, transform, and argue their preferences (Bouyssou 1990). A criterion allows establishing preference relations between alternatives; thus, the quality of the construction is crucial for the decision process. For assessing synergies among the Rio Conventions at the project level, decision criteria need to reflect global (UNFCCC, CBD, and UNCCD) and local interests. We have based our identification of criteria on the various ecosystem services forests provide, adopting the Millennium Ecosystem Assessment classification (MA 2005). 
Most supporting services, such as the primary production of the ecosystem and photosynthesis, are of global interest. Provisioning services, such as timber and wood fuel, are linked to the local interest of farmers, while the CBD has interest in the protection of genetic resources, biochemical, natural medicines, pharmaceuticals, and ornamental resources. Regulating services such as disease regulation, pest regulation, pollination, and seed dispersal are important issues, for instance, at local level. Cultural services are mainly significant at the local level, while some of these issues are also being addressed under the UNCCD, such as spiritual and religious values and knowledge systems. This analysis provided us with the initial framework for addressing synergies and gave us the background for selecting a set of criteria (for a further description see Cóndor 2008; Cóndor et al. 2009).

We selected a set of decision criteria (no 15) based on the forest ecosystem services analysis, extensive bibliographic research on sustainable development criteria applied to the assessment of projects, and case studies/experience from forestry projects (see Cóndor 2008).

\subsection{Expert participation}

Sell et al. (2006) involved forestry experts that were asked to nominate criteria for assessing tropical forestry projects providing environmental services. They obtained 260 single criteria nominations, which then were allocated and renamed into 25 criteria. For this study, in order to validate the set of decision criteria for the assessment of synergies at the project level, experts were invited to participate in a questionnaire between September 2006 and January 2007. Various stakeholders participating in the Rio Conventions were invited, such as: the Ad Hoc Technical Expert Group (AHTEG) on biodiversity and climate change and the AHTEG on forestry (CBD), the roster of independent experts on forestry (UNCCD), as well as experts from afforestation/reforestation (UNFCCC). Other experts such as participants to the global workshops on synergies (in Finland and Italy) and the workshop on deforestation organized by the Food and Agriculture Organisation (FAO) in 2006, worldwide forest institutions, and experts subscribed to the Forest Policy Info Mailing List were also involved.

English and Spanish versions of the questionnaire were prepared. ${ }^{3}$ In the questionnaire, we proposed to the experts a set of macro (social, economic and environmental) and micro criteria. They were asked to assess the importance of criteria, and to suggest their own criteria in case they did not found the ones we proposed representative. The questionnaire provided a tree-like structure (hierarchy) proposing the evaluation of macro and micro criteria. Depending on the circumstances of the decision process, there are different ways in which criteria can be defined. However, we found that the hierarchy proposal was an approach to facilitate and involve the experts.

\subsection{Indicators}

We developed ad hoc indicators based on the information available from the forestry projects (alternatives) in order to operationalize the criteria. An iterative process, which alternates between reading PDDs and revising indicators was useful in this regard. Due to

\footnotetext{
3 Interested persons can contact the authors to obtain the questionnaire.
} 
the different types of interventions and various locations of the projects, an ordinal scale of evaluation was adopted for these indicators. An ordinal scale (qualitative) denotes the position in an ordered sequence (e.g. insufficient, good, very good). Instead, a cardinal scale (quantitative) is a meaningful measurement scale that would allow for comparison across alternatives. Kangas et al. (2001) argues that in natural resources management, descriptive expressions instead of quantitative measures and qualitative or ordinal information are common. Kangas and Kangas (2005) state that it would often be easier to express ordinal than cardinal preferences for many decision makers and for stakeholders in participatory approaches; thus, ordinal statements may reflect the true preferences better than exact cardinal values. An advantage of the ELECTRE TRI model is that criteria may also be ordinal (Arondel and Girardin 2000; Srinivasa Raju et al. 2000).

Another group of experts was contacted for a personal interview. National experts working in the field with international projects ( 6 participants) and experts from the FAO Forestry Department (5 participants) were contacted. These interviews took place between June and October 2007. The objective of the personal interviews was to identify technical and specific improvements for the indicators, and to establish an appropriate scale of evaluation. The scale of evaluation related to each indicator was constructed in different ways. In some cases, a 'yes' or 'no' response was applicable $(\mathrm{Cr} 1, \mathrm{Cr} 5, \mathrm{Cr} 10, \mathrm{Cr} 11)$ and in other cases a direct evaluation was performed $(\mathrm{Cr} 2, \mathrm{Cr} 3, \mathrm{Cr} 4, \mathrm{Cr} 6, \mathrm{Cr} 8, \mathrm{Cr} 9, \mathrm{Cr} 12)$. Direct contact with the experts allowed us to discuss and define criteria and indicators for the assessment with the ELECTRE TRI model.

\section{Results}

\subsection{Criteria and indicators}

The scale of evaluation and the level of interest (global or local) of criteria and indicators are shown in Table 2. During the selection of criteria, we organized information and focused on a sufficient number of decision criteria. The total number is related to the complexity and multidimensional purpose of assessing synergies at the project level.

We received a response to the questionnaire from 97 experts. Two main groups were differentiated: policymakers (including ministries of environment, agriculture, and forests, as well as environmental agencies, and departments for international cooperation) and scientists (forestry research institutions, universities, and NGOs). We received responses from 44 different countries. Forty-one $(41 \%)$ were coming from the top 10 countries in terms of forest coverage. Fifty-eight $(58 \%)$ of participants were scientists and forty-two $(42 \%)$ policymakers.

Through the questionnaire, we proposed 15 micro criteria, while including the possibility to propose new ones. The mean and standard deviation of weights for macro criteria by continent are displayed in Fig. 3. The test of homogeneity of variance shows that variance of the continents is similar for the three macro criteria. The one-way Analysis of Variance (ANOVA) shows that there is no difference between the means for the social criterion ( $d f=3, F=0.94$, sig $=0.42$ ). But there is a difference between means for the economic $(d f=3, \quad F=3.16, \quad$ sig $=0.03)$ and environmental $(d f=3, \quad F=5.22$, $\operatorname{sig}=0.002)$ criteria.

A representation of the means and standard deviation of weights for micro criteria is given in Fig. 4. We selected a certain number of criteria, according to the information obtained from the questionnaire. Based on the importance given by participants, the 
Table 2 Decision criteria, indicators, level of interest and scale evaluation description

\begin{tabular}{|c|c|c|c|c|c|c|c|}
\hline Macro & Interest & Micro & Indicator & \multicolumn{2}{|c|}{ Response/evaluation } & Score & Description \\
\hline \multirow[t]{10}{*}{ Social } & \multirow[t]{10}{*}{ Local } & \multirow{10}{*}{$\begin{array}{l}\text { Land tenure } \\
(\mathrm{Cr} 1)\end{array}$} & \multirow{4}{*}{$\begin{array}{l}\text { Clear defined } \\
\text { land tenure }\end{array}$} & \multirow[t]{3}{*}{ Yes } & Very good & 7 & Clearly described in the project, documented. \\
\hline & & & & & Good & 5 & More or less clearly described in the project. \\
\hline & & & & & Scarce & 3 & Not enough information. \\
\hline & & & & No & Null & 1 & Not documented or land tenure is not secure. \\
\hline & & & \multirow{4}{*}{$\begin{array}{l}\text { Long term } \\
\text { Land tenure }\end{array}$} & \multicolumn{2}{|c|}{$31->50$ years } & 1 & \\
\hline & & & & \multicolumn{2}{|c|}{ 11-30 years } & 0.7 & Enhance biodiversity and conservation of soils \\
\hline & & & & \multicolumn{2}{|c|}{ 6-10 years } & 0.3 & \\
\hline & & & & \multicolumn{2}{|c|}{$0-5$ years } & 0 & \\
\hline & & & \multirow{2}{*}{$\begin{array}{l}\text { Achieve land } \\
\text { tenure } \\
\text { with the project }\end{array}$} & \multicolumn{2}{|l|}{ Yes } & 1 & - \\
\hline & & & & \multicolumn{2}{|l|}{ No } & 0 & - \\
\hline \multirow[t]{4}{*}{ Social } & \multirow[t]{4}{*}{$\begin{array}{l}\text { Local - } \\
\text { Global } \\
(\mathrm{CBD})\end{array}$} & \multirow{4}{*}{$\begin{array}{l}\text { Equitably } \\
\text { share natural } \\
\text { resources/ben } \\
\text { efits of } \\
\text { development } \\
\text { (Cr2) }\end{array}$} & \multirow{4}{*}{$\begin{array}{l}\text { Different } \\
\text { stakeholders } \\
\text { which } \\
\text { take advantage of } \\
\text { the project }\end{array}$} & \multicolumn{2}{|c|}{ Large proportion } & 7 & $\begin{array}{l}\text { Different local participants are involved. Example: } \\
\text { NGO, local administration, farmers, communities, } \\
\text { government, etc. }\end{array}$ \\
\hline & & & & \multicolumn{2}{|c|}{ Medium proportion } & 5 & $\begin{array}{l}\text { Some local participants are involved. Example: a } \\
\text { number of private entities or farmers/communities and } \\
\text { local entities. }\end{array}$ \\
\hline & & & & \multicolumn{2}{|c|}{ Small proportion } & 3 & $\begin{array}{l}\text { Few local participants are involved. Example: two } \\
\text { institutions are involved. }\end{array}$ \\
\hline & & & & \multicolumn{2}{|c|}{ Very low proportion } & 1 & $\begin{array}{l}\text { Only one participant is involved in the project and no } \\
\text { local participants are considered. }\end{array}$ \\
\hline \multirow[t]{4}{*}{ Social } & \multirow[t]{4}{*}{ Local } & \multirow{4}{*}{$\begin{array}{l}\text { Skill } \\
\text { development } \\
(\mathrm{Cr} 3)\end{array}$} & \multirow{4}{*}{$\begin{array}{l}\text { Skill } \\
\text { development } \\
\text { of project } \\
\text { stakeholders }\end{array}$} & \multicolumn{2}{|c|}{ Well defined } & 7 & Defined a training programme. \\
\hline & & & & \multicolumn{2}{|c|}{ Sufficient } & 3 & $\begin{array}{l}\text { Defined capacity building (punctual aspects) during } \\
\text { the project. }\end{array}$ \\
\hline & & & & Scarc & & 5 & Only in some moment of the project, not well defined. \\
\hline & & & & Nopl & & 1 & Not defined skill development in the project. \\
\hline Social & Local & & & High & icipation & 7 & Participatory process incorporated in the project. \\
\hline & & Ensure local & Stakeholder & Mode & participation & 5 & $\begin{array}{l}\text { Local participation only in some aspects of the } \\
\text { project. }\end{array}$ \\
\hline & & participation & participation in & Small & ticipation & 3 & Very little involvement. \\
\hline & & & project activities & No pa & ipation & 1 & $\begin{array}{l}\text { Local stakeholders have not been involved in the } \\
\text { process. }\end{array}$ \\
\hline Economic & Local & & & Yes & Very good & 7 & $\begin{array}{l}\text { Clear involvement of local people, direct and indirect } \\
\text { employment from project implementation. }\end{array}$ \\
\hline & & & $\begin{array}{l}\text { Direct and } \\
\text { indirect }\end{array}$ & & Good & 5 & $\begin{array}{l}\text { More or less clearly defined the direct or indirect } \\
\text { involvement of local people. }\end{array}$ \\
\hline & & Employment & $\begin{array}{l}\text { employment for } \\
\text { local people }\end{array}$ & & Scarce & 3 & $\begin{array}{l}\text { Not clear/not enough information of local people } \\
\text { involvement. }\end{array}$ \\
\hline & & & & No & No evidence & 1 & No evidence of employment for local people. \\
\hline & & & & Long & & 1 & Long term employment ( $>5$ years) \\
\hline & & & Term of the & Medi & erm & 0.7 & Medium term employment (1- 5 years) \\
\hline & & & employment & Short & & 0.3 & Short term employment (some months) \\
\hline & & & & Very & t term & 0 & Very short term employment (some weeks) \\
\hline Economic & Local & $\begin{array}{l}\text { Financial } \\
\text { returns to }\end{array}$ & $\begin{array}{l}\text { Financial returns } \\
\text { through }\end{array}$ & High & & 7 & $\begin{array}{l}\text { High number of product diversification. Example: } \\
\text { Forest and agricultural/crop product. }\end{array}$ \\
\hline & & $\begin{array}{l}\text { local entities } \\
\text { (Cr6) }\end{array}$ & $\begin{array}{l}\text { diversification of } \\
\text { local economy }\end{array}$ & Medi & & 5 & $\begin{array}{l}\text { Medium number of products diversification. Example: } \\
\text { some forest and/or agricultural products. }\end{array}$ \\
\hline & & & & Small & & 3 & Small diversification, forest products. \\
\hline & & & & Very & & 1 & $\begin{array}{l}\text { Single use of the forest (link with one specie } \\
\text { cultivation) }\end{array}$ \\
\hline
\end{tabular}


Table 2 continued

\begin{tabular}{|c|c|c|c|c|c|c|c|}
\hline Macro & Interest & Micro & Indicator & \multicolumn{2}{|c|}{ Response/evaluation } & Score & Description \\
\hline \multirow[t]{4}{*}{ Economic } & \multirow{4}{*}{$\begin{array}{l}\text { Local- } \\
\text { Global } \\
\text { (UNFCCC) }\end{array}$} & \multirow{4}{*}{$\begin{array}{l}\text { Financial } \\
\text { forestry } \\
\text { incentives } \\
\text { (Cr8) }\end{array}$} & \multirow{4}{*}{$\begin{array}{l}\text { Define } \\
\text { financial forestry } \\
\text { incentives in the } \\
\text { project }\end{array}$} & \multicolumn{2}{|c|}{ High } & 7 & $\begin{array}{l}\text { Incentives: carbon credits and payment for other } \\
\text { environmental services. }\end{array}$ \\
\hline & & & & \multicolumn{2}{|c|}{ Medium } & 5 & $\begin{array}{l}\text { Incentives: payment for some forest environmental } \\
\text { services. }\end{array}$ \\
\hline & & & & \multicolumn{2}{|c|}{ Small } & 3 & $\begin{array}{l}\text { Incentives: carbon credits or other forest } \\
\text { environmental service. }\end{array}$ \\
\hline & & & & \multicolumn{2}{|l|}{ Null } & 1 & No incentives at all. \\
\hline \multirow[t]{4}{*}{ Environmental } & \multirow{4}{*}{$\begin{array}{l}\text { Local- } \\
\text { Global } \\
(\mathrm{CBD})\end{array}$} & \multirow{4}{*}{$\begin{array}{l}\text { Use of native } \\
\text { species } \\
(\mathrm{Cr} 9)\end{array}$} & \multirow{4}{*}{$\begin{array}{l}\text { Define the use of } \\
\text { native } \\
\text { species and/or } \\
\text { exotic species }\end{array}$} & \multicolumn{3}{|c|}{7} & Use of native species. \\
\hline & & & & \multicolumn{3}{|c|}{5} & $\begin{array}{l}\text { Use of native species and justified use of exotic } \\
\text { species. }\end{array}$ \\
\hline & & & & \multicolumn{3}{|c|}{3} & $\begin{array}{l}\text { Use of native species and not justified use of exotic } \\
\text { species. }\end{array}$ \\
\hline & & & & \multicolumn{3}{|c|}{1} & Only use of exotic species, not justified. \\
\hline \multirow[t]{4}{*}{ Environmental } & \multirow{4}{*}{$\begin{array}{l}\text { Local- } \\
\text { Global } \\
\text { (UNCCD) }\end{array}$} & \multirow{4}{*}{$\begin{array}{l}\text { Conservation } \\
\text { and } \\
\text { maintenance } \\
\text { of soil } \\
\text { resource } \\
(\mathrm{Cr} 10)\end{array}$} & \multirow{4}{*}{$\begin{array}{l}\text { Procedures } \\
\text { to conserve and } \\
\text { maintain soils } \\
\text { (during } \\
\text { the project) }\end{array}$} & \multirow[t]{3}{*}{ Yes } & Very good & 7 & $\begin{array}{l}\text { Clear indications of measures to be taken for soil } \\
\text { conservation. }\end{array}$ \\
\hline & & & & & Good & 5 & $\begin{array}{l}\text { Some indications of measures to be considered for soil } \\
\text { conservation. }\end{array}$ \\
\hline & & & & & Scarce & 3 & $\begin{array}{l}\text { No clear indications if there will be measures for soil } \\
\text { conservation. }\end{array}$ \\
\hline & & & & No & Null & 1 & $\begin{array}{l}\text { No measures described or considered for soil } \\
\text { conservation. }\end{array}$ \\
\hline \multirow[t]{4}{*}{ Environmental } & \multirow{4}{*}{$\begin{array}{l}\text { Local- } \\
\text { Global } \\
\text { (CBD, } \\
\text { UNCCD) }\end{array}$} & \multirow{4}{*}{$\begin{array}{l}\text { Conservation } \\
\text { and } \\
\text { maintenance } \\
\text { of water } \\
\text { resource } \\
(\text { Cr11) }\end{array}$} & \multirow{4}{*}{$\begin{array}{l}\text { Procedures } \\
\text { to conserve and } \\
\text { maintain water } \\
\text { resources }\end{array}$} & \multirow[t]{3}{*}{ Yes } & Very good & 7 & $\begin{array}{l}\text { Clear indications of measures to be taken for water } \\
\text { conservation. }\end{array}$ \\
\hline & & & & & Good & 5 & $\begin{array}{l}\text { Some indications of measures to be considered for } \\
\text { water conservation. }\end{array}$ \\
\hline & & & & & Scarce & 3 & $\begin{array}{l}\text { No clear indications if there will be measures for } \\
\text { water conservation. }\end{array}$ \\
\hline & & & & No & Null & 1 & $\begin{array}{l}\text { No measures described or considered for water } \\
\text { conservation. }\end{array}$ \\
\hline \multirow[t]{4}{*}{ Environmental } & \multirow{4}{*}{$\begin{array}{l}\text { Local- } \\
\text { Global } \\
(\mathrm{CBD})\end{array}$} & \multirow{4}{*}{$\begin{array}{l}\text { Biodiversity } \\
\text { conservation } \\
(\mathrm{Cr} 12)\end{array}$} & \multirow{4}{*}{$\begin{array}{l}\text { Diversity of } \\
\text { composition } \\
\text { of forest } \\
\text { plantations5 }\end{array}$} & \multicolumn{2}{|l|}{ High } & 7 & High diversity in forest composition. \\
\hline & & & & \multicolumn{2}{|c|}{ Medium } & 5 & Medium diversity in forest composition. \\
\hline & & & & \multicolumn{2}{|l|}{ Low } & 3 & Low diversity in forest composition. \\
\hline & & & & \multicolumn{2}{|l|}{ Null } & 1 & No diversity, single specie. \\
\hline
\end{tabular}

Note: Cr 7 (infrastructure) was not used for the final assessment

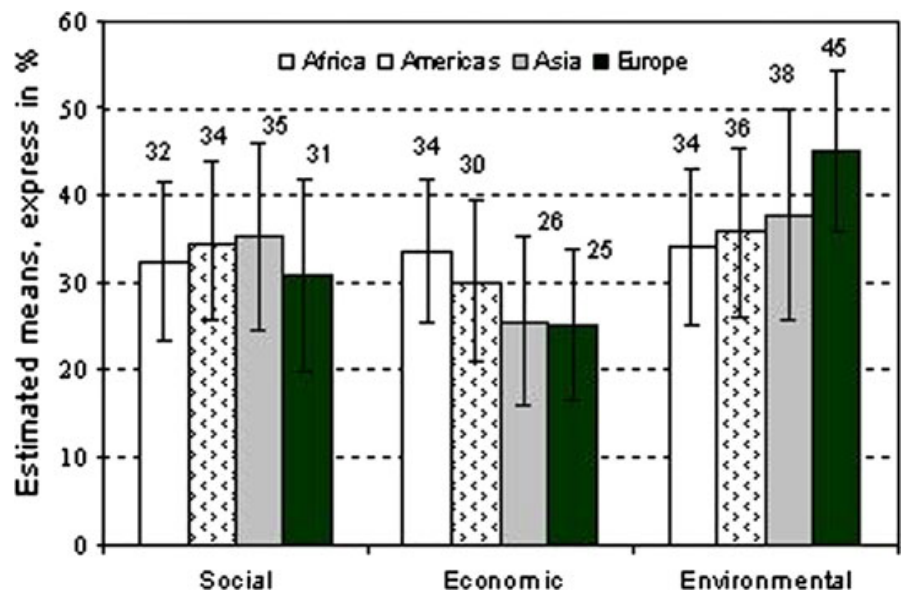

Fig. 3 Estimated means obtained for macro criteria from the questionnaire provided to the experts 


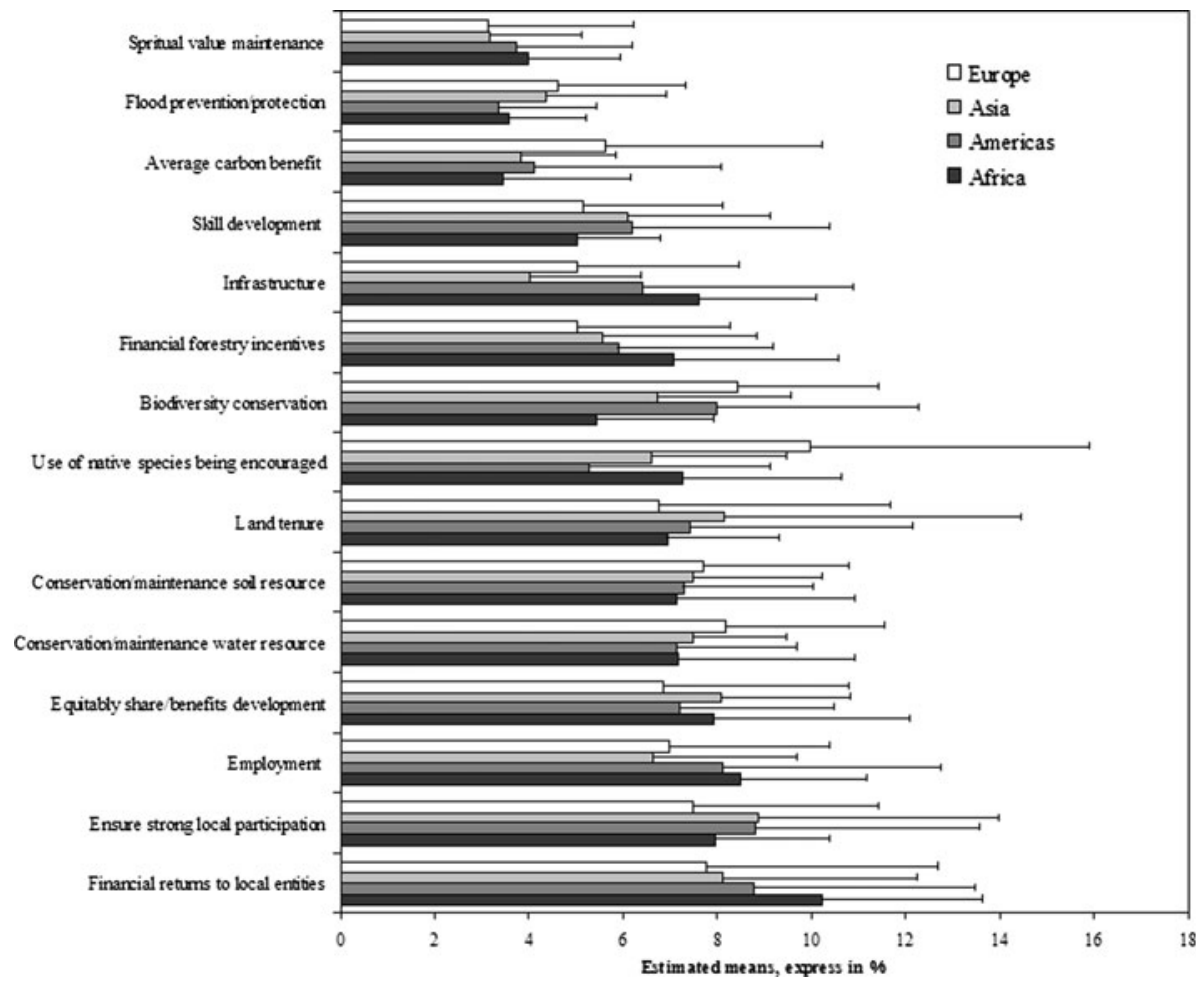

Fig. 4 Estimated means obtained for micro criteria from the questionnaire provided to the experts

requirements set by the application of the model (a limited number of criteria) and previous experiences with the ELECTRE TRI model, a social (spiritual value maintenance) and an environmental (flood prevention/protection) criterion was excluded from the analysis. In fact, these criteria were mostly linked to local conditions in some regions of the world and do not represent global interests, which is the focus of our assessment. We kept the 'average carbon benefit' criterion because it is representative for the UNFCCC objective. Further analysis of the questionnaire is available in Cóndor (2008).

The next step was the presentation of criteria and indicators to another group of experts that were interviewed personally (no 11). This exercise allowed us to improve the scale of evaluation. We have incorporated most of the suggestions given by the experts. They agreed to use a limited number of criteria. Therefore, after the interview process, another criterion was excluded (average carbon benefit).

\subsection{Model evaluation}

Criteria and indicators were qualitative and have an increasing direction (the higher the evaluation, the better the alternative). During the assessment, we realized that it was not possible to get enough information on one economic criterion (infrastructure). Therefore, eleven (no 11) decision criteria were defined for the final project assessment. This number of criteria is in line with the number used in similar studies. Previous model evaluations with ELECTRE TRI suggest to use 13 criteria for sorting cropping systems on the basis of 
their impact on groundwater quality (Arondel and Girardin 2000) or 10 criteria for the analysis of sustainable water resources planning (Srinivasa Raju et al. 2000). For a sorting procedure in public administration, 12 criteria were proposed (Norese and Viale 2002).

Three categories to classify projects were adopted: $\mathrm{C} 1$ = 'synergistic' (first category), $\mathrm{C} 2=$ 'reasonably synergistic' (second category), and C3 = 'not synergistic' (third category). The number of categories is simple to manage and based on the fact that projects can be distinguished among them. Two profiles that divided the three categories were defined. The Pr01 (bl) profile corresponds to the minimum values of the criteria set that a project must receive to be considered in $\mathrm{C} 1$. The Pr02 (b2) profile corresponds to the values of the criteria set that a project must have as a minimum to be considered in $\mathrm{C} 2$, but does not belong to $\mathrm{C} 1$ or $\mathrm{C} 3$. Reference profiles were chosen based on the minimum standard and technical information acquired from a literature review. In some situations, the construction of profiles suggested to include information from already existing standards (Arondel and Girardin 2000) or a proportion of the scale of evaluation is considered (Madlener et al. 2009). For this study, profiles of the criteria were fixed based on the ordinal scale of evaluation. For most criteria, the Pr01 and Pr02 were 5 and 3, respectively; instead, for the 'land tenure' (Cr1) and 'employment' (Cr5) criteria, the Pr01 was 6.

Other parameters used for the evaluation model such as the weights, thresholds (indifference, preference, and veto), and cutting level were also defined. The relative importance of criteria (weights) used with ELECTRE TRI are shown in Table 3. The attribution of weights to each criterion allows showing the impact of a decision. Some studies have not considered the use of weights when implementing ELECTRE TRI model (Andre 2007; Siskos et al. 2007). However, we found the use of weights relevant for this assessment (see Arondel and Girardin 2000; Srinivasa Raju et al. 2000; Rousval 2005). Thresholds were defined for the profiles in terms of the ordinal scale. We assumed that the difference of one score does not allow differentiating between two projects; instead, a difference of two scores can constitute a difference. The preference $(p)$ and indifference $(q)$ thresholds were $p=2$ and $q=1$, respectively, while for the veto threshold $(v)$, we assumed $v=3$ for all criteria. Kangas et al. (2001) describe that the veto threshold is a very powerful tool, by which the importance of the considered criteria can be greatly emphasized. Besides, the veto threshold is an additional instrument to limit the risk of

Table 3 Set of weights for the decision criteria

\begin{tabular}{|c|c|c|c|}
\hline \multicolumn{2}{|c|}{ Forestry criteria } & \multirow{2}{*}{$\frac{\text { Weight }(\%)}{9.12}$} & \multirow{2}{*}{$\begin{array}{l}\text { Standard deviation } \\
0.8\end{array}$} \\
\hline $\mathrm{Cr} 1$ & Land tenure & & \\
\hline $\mathrm{Cr} 2$ & Equitably share/benefits development & 9.36 & 0.7 \\
\hline $\mathrm{Cr} 3$ & Skill development & 7.01 & 0.8 \\
\hline $\mathrm{Cr} 4$ & Ensure strong local participation & 10.32 & 0.9 \\
\hline $\mathrm{Cr} 5$ & Employment & 9.42 & 1.1 \\
\hline Cr6 & Financial returns to local entities & 10.86 & 1.3 \\
\hline $\mathrm{Cr} 8$ & Financial forestry incentives & 7.34 & 1.1 \\
\hline $\mathrm{Cr} 9$ & Use of native species being encouraged & 9.07 & 2.4 \\
\hline $\mathrm{Cr} 10$ & Conservation and maintenance of soil resource & 9.24 & 0.3 \\
\hline Cr11 & Conservation and maintenance of water resource & 9.34 & 0.6 \\
\hline Cr12 & Biodiversity conservation & 8.91 & 1.7 \\
\hline
\end{tabular}

Mean weights were obtained from all participants; Cr 7 (infrastructure) was not used for the final assessment 
compensation, penalizing relevant deviations on specific criteria. Thresholds and cutting level were determined by interactive use of the ELECTRE TRI software. A sensitivity analysis was used as a single integrated approach while defining these parameters. We used the default value as proposed by ELECTRE TRI software $(\lambda=0.76)$. We found that a lower value, for instance, $\lambda=0.70$, allowed to assign projects to two categories $(\mathrm{C} 2, \mathrm{C} 1)$. Since we wanted to better differentiate the assignments of the projects, we used a higher value that allows sorting projects into three categories.

An integrated evaluation with 11 decision criteria was executed. The performance matrix of the projects is shown in Table 4 . We carefully analyzed and listed all qualitative and quantitative information available from PDDs. Based on the decision criteria and indicators, we assigned the scores to each project. Olsen and Fenhann (2008) argue that analyses of PDDs are likely to measure only positive contributions to sustainable development since project developers are unlikely to write about negative aspects of their projects. However, we sought to overcome this problem by constructing a scale of assessment for the indicators. In this way, it was possible to differentiate and assess information contained in the PDDs. Results from the ELECTRE TRI assessment are shown in Table 5. We followed the pessimistic (conservative) approach of ELECTRE TRI for this assessment. Then, according to this approach, two forestry projects (FP9, FP2) were assigned to the C1 (synergistic). FP9 and FP2 projects implement agroforestry/sylvopastoral systems and restoration of degraded lands interventions, respectively. The FP9 project in Colombia seeks to establish forestry, agroforestry, and sylvopastoral systems on abandoned pastures, and secure their sustainable management with active community participation. The project aims to generate financial resources and improvement of livelihoods of small-scale landholders; sustainable management of watersheds; conservation of biodiversity; and active participation and involvement of local communities, NGOs, government, and the private sector of the area. FP2 is the Moldova Soil Conservation

Table 4 Performance matrix of forestry projects

\begin{tabular}{lllllllllll}
\hline & FP1 & FP2 & FP3 & FP4 & FP5 & FP6 & FP7 & FP8 & FP9 & FP10 \\
\hline Cr1 & 7 & 6 & 6 & 6 & 7 & 7 & 7.7 & 2 & 5 & 7 \\
Cr2 & 5 & 5 & 4 & 5 & 1 & 5 & 3 & 4 & 7 & 1 \\
Cr3 & 5 & 7 & 3 & 5 & 3 & 5 & 5 & 6 & 6 & 1 \\
Cr4 & 6 & 5 & 5 & 4 & 2 & 3 & 4 & 5 & 7 & 3 \\
Cr5 & 3 & 6.7 & 5.7 & 5.7 & 3 & 5 & 5 & 4 & 6 & 3 \\
Cr6 & 3 & 3 & 3 & 7 & 1 & 5 & 3 & 3 & 7 & 1 \\
Cr8 & 4 & 5 & 3 & 3 & 3 & 3 & 4 & 3 & 5 & 3 \\
Cr9 & 5 & 5 & 5 & 7 & 1 & 5 & 7 & 2 & 6 & 7 \\
Cr10 & 5 & 7 & 6 & 3 & 5 & 5 & 5 & 5 & 3 & 5 \\
Cr11 & 7 & 5 & 3 & 3 & 5 & 5 & 3 & 3 & 4 & 3 \\
Cr12 & 6 & 5 & 6 & 5 & 2 & 3 & 5 & 3 & 8 & 7
\end{tabular}

This table represents the evaluation of the projects with each forestry criteria. FP, forestry project; FP1, China; FP2, Moldavia; FP3, Albania; FP4, Honduras; FP5, Brazil; FP6, China; FP7, Ecuador; FP8, Madagascar; FP9, Colombia; FP10, Brazil (for further description see Table 2). Cr, decision criteria; Cr1, land tenure; $\mathrm{Cr}$ 2, equitably share/benefits development; $\mathrm{Cr} 3$, skill development; $\mathrm{Cr} 4$, ensure strong local participation; Cr5, employment; Cr6, financial returns to local entities; Cr8, financial forestry incentives; $\mathrm{Cr}$, use of native species being encouraged; Cr10, conservation and maintenance of soil resource; Cr11, conservation and maintenance of water resource; $\mathrm{Cr} 12$, biodiversity conservation (for further description see Table 3) 
Table 5 Results from ELECTRE TRI: assignment by alternative

\begin{tabular}{lll}
\hline Projects (alternative) & \multicolumn{2}{c}{ Assignment } \\
\cline { 2 - 3 } & Pessimistic & Optimistic \\
\hline FP1 & C2 2 \\
FP2 & C1 & C2 \\
FP3 & C2 1 \\
FP4 & C2 & C2 \\
FP5 & C3 & C2 \\
FP6 & C2 & C2 \\
FP7 & C2 & C2 \\
FP8 & C2 & C2 \\
FP9 & C1 & C2 \\
FP10 & C3 & C1 \\
\hline
\end{tabular}

This table shows the output obtained with the ELECTRE TRI model. Both pessimistic and optimistic assignments are shown. For this study, a conservative approach was adopted, therefore, only the pessimistic assignment was considered for discussion. FP, forestry project (list of project are shown in Table 2); $C$ are the categories selected for this study; where $\mathrm{C} 1$, synergistic category; $\mathrm{C} 2$ reasonably synergistic category; C3 not synergistic category

Project, which proposes to achieve multiple objectives in terms of the restoration of degraded lands through improvement in the vegetative cover, enhanced supplies of forest products to local communities, and increases in greenhouse gas removals from the degraded lands.

Two projects (FP5, FP10) were assigned to C3 (not synergistic). The FP5 and FP10 are both large-scale plantations projects implemented in Brazil. The FP5 project aims the establishment of plantations as a renewable source of wood supplies for energy to meet the industrial needs (iron and steel industry). Benefits are expected from the generation of carbon stocks and the use of sustainable sources of biomass in place of fossil fuels. The FP10 project activity proposed as A/R of riparian areas that are currently occupied by unmanaged grassland and to be reforested using a composition of native species tree buds. The A/R activity will avoid invasions of the riparian areas by settlers for urban lots or any other type of construction.

Six projects (FP1, FP3, FP4, FP6, FP7, FP8) were assigned to the C2 (reasonably synergistic) category. The FP1 project aims to facilitate reforestation for Guangxi Watershed Management in Pearl River Basin (China), where activities include forest restoration in small watershed areas; enhance biodiversity conservation by increasing the connectivity of forests adjacent to pasture reserves; improve soil and water erosion control; and generate income for local communities. The FP3 project aims to implement the assisted natural regeneration of degraded lands in Albania. Activities include A/R of degraded lands by setting aside and protecting land to make natural re-growth possible, leading to enhanced sources of livelihood and incomes in poor rural areas, reduced soil degradation, improved water quality, and conservation of biodiversity. The FP6 project aims afforestation for combating desertification in China. Activities include carbon sequestration; creating job opportunities and improving socio-economic conditions within the area of influence of the project; improving local environmental conditions; and developing, testing, and disseminating the best practice in desertification combating and strengthening capacity building through support for training and technical assistance to the 
relevant agencies and communities. FP7 aims to implement the Chocó-Manabí Corridor Reforestation and Conservation Carbon Project in Ecuador. This project provides longterm benefits for climate, biodiversity and watershed protection in a region identified both nationally and internationally as a top conservation and sustainable development priority. FP4 and FP8 projects are described in the discussion section.

Table 5 shows that with the pessimistic and optimistic approach, the FP2 and FP9 projects are stable in the assignment (category $\mathrm{C} 1$ ). The same applies for the FP1, FP3, FP4, FP6, FP7, and FP8 projects (category C2), where the evaluation of the projects is between the two profiles of a category. However, the FP5 and FP10 projects are assigned to the $\mathrm{C} 3$ and $\mathrm{C} 2$ categories according to the pessimistic and optimistic approach, respectively. This means that the projects are incomparable to one or several profiles; thus, the pessimistic assignment rule assigns the alternative to a lower category. This is just to show that the two procedures of the ELECTRE TRI model are an advantage while dealing with incomparability between the profiles and alternatives.

\section{Discussion}

Through the assessment, ten forestry PDDs were classified into three categories. This means that there are some types of forestry interventions, for instance, agroforestry or restoration of degraded lands projects, which comply with a higher number of criteria $(\mathrm{C} 1$ synergistic) compared to large-scale plantation projects (C3 not synergistic). Indeed, economic, social and environmental benefits are attributed to agroforestry projects (Smith and Scherr 2002; Barker et al. 2007). Agroforestry systems include a wide variety of practices such as agrosilvicultural systems; silvopastoral systems; and tree-based systems such as fodder plantations, shelterbelts, and riparian forest buffers. Moreover, Appanah (2003) shows that rehabilitation procedures seek to go beyond that of commercial timber production, and trials are underway to increase biodiversity and ecological services as additional products. Therefore, the majority of forest restoration schemes can also provide additional income to rural communities. In fact, these characteristics are included in the FP2 project, which had high scores on the social and environmental criteria. On the other hand, Smith and Scherr (2002) explain that large-scale industrial plantations and strict forest protection pose considerable risks for communities, the most significant among them being loss of access to land and forests which communities have long used under customary law. Barker et al. (2007) describe that plantations can contribute positively to employment, economic growth, exports, renewable energy supply, and poverty alleviation, but may also lead to negative social impacts such as loss of grazing land and sources of traditional livelihoods. In fact, FP5 and FP10 projects have the lowest evaluation for the social Cr2 (equitably share natural resources), $\mathrm{Cr} 3$ (skill development), and $\mathrm{Cr} 4$ (ensure local participation) criteria. Others have pointed out the negative and positive impacts of forestry projects. For instance, in terms of environmental benefits, native forest management options, particularly, concession forests, offer a great deal of secondary benefits with great relevance to biodiversity protection. For the development impacts, plantations are more important for the activity level of the economy as a whole, but less for the regional economy. In terms of regional benefits, private sustainable logging in native forests is more relevant (Halsnæs and Markandya 2002). Totten et al. (2003) described that projects that offer the greatest synergies include the prevention of deforestation, the ecological restoration of fragmented landscapes, the sustainable improvement of agro-ecological farming 
systems, and the expansion of new growth on degraded lands. In addition, these projects have the potential to reduce overall carbon mitigation costs, to protect threatened and endangered species and habitats, which deliver critical ecosystem and climate adaptation services, and to provide sustainable development opportunities to local communities.

Further information was obtained from the ELECTRE TRI model. The FP4 and FP8 projects were assigned to the second category (C2 reasonably synergistic). The FP4 project in Honduras aims at reforestation around the Pico Bonito National Park. Activities for this project include agroforestry for small scale producers, natural forest restoration through reforestation of degraded land for conservation, and reforestation for sustainable commercial forestry. The FP8 project in Madagascar aims to acquire carbon emission reduction and wood chips for pulp materials on degraded land. A component of this project is also to support the 'community forest of the local inhabitants'. Therefore, local inhabitants will plant free seedlings donated by the project participants, manage the forest by themselves in addition to the industrial plantation activity. The assignment of FP4 (reforestation/agroforestry) and FP8 (large plantation) projects to the C2 category shows that not only a certain type of intervention can offer synergies (FP9 agroforestry or FP2 restoration), but attention has to be paid to the way in which they are planned and implemented. That is the reason why the FP4 project was not assigned to the C1 category and the FP8 project to the C3 category. Indeed, the impact of forestry project activities are beneficial or adverse depending on the selection of practices within the activity; the management options related to the activity; the biological and physical conditions of the area; and the socio-economic conditions of the region (UBA 2001, 2004b).

Results obtained with the ELECTRE TRI model do not only provide an assignment of the projects into categories. However, it also provides us with information on the ex-ante performance of the projects through an integrated multicriteria assessment using 11 decision criteria. From a theoretical point of view, we argue that assessing synergies among the Rio Conventions at the project level also implies assessing the sustainability of forestry projects, keeping in mind that the main objective of the Rio Conventions is to accomplish sustainable development. An in-depth review of how the PDDs contribute to sustainable development under the CDM was presented by Olsen (2007).

From the methodological point of view, we have faced the concept of trade-offs. Olsen (2007) has indicated that in general trade-offs between different aspects of sustainable development exist, and that these are resolved in favour of cost-effectiveness.

Non-forestry PDDs have also been assessed with compensatory multicriteria methods. Notably, Sutter and Parreño (2007) have developed and applied an elaborate approach (MATA-CDM) based on the Multiple Attribute Utility Theory. The only disadvantage of this method is that information is aggregated into a single value, which implies compensation. Olsen and Fenhann (2008) have developed a taxonomy for sustainability assessment based on PDD text analysis, where also forestry projects were considered. In contrast, our study has for the first time addressed the choice of an appropriate multicriteria method for measuring strong sustainability on forestry projects through a non-compensatory multicriteria method. This method seeks to establish the evidence for favouring the project that performs the best on the greatest number of criteria. For assessing synergies at the project level, we did not want to identify the best project or rank them, because no quantifiable information on the performance could be obtained. However, sorting them means that we will be able to identify those projects that comply with a higher number of criteria. The higher the assignment of the projects, the better the performance of the project. In those cases, more synergistic characteristics are expected during the implementation of the project. The selection of the decision criteria play an important role, as these $\mathrm{A} / \mathrm{R}$ projects 
are assessed under specific global and local objectives. Through this assessment, we can come to a compromise solution of a problem with multidimensional and conflicting criteria including social, economic and environmental features-achieving synergies among the Rio Conventions.

\section{Conclusions}

The lack of methodologies for assessing synergies among the Rio Conventions at the project level was defined as the problem situation. We believe that providing decision support is much more important than just adopting a methodological tool to solve a decision problem. Thus, we propose to conduct a decision aiding process, which encouraged reasoning and revising all steps undertaken. During the process, we concentrated efforts on defining decision criteria. Thus, forestry experts were involved through a questionnaire and personal interviews in the validation and improvement of criteria and indicators. Interaction and consultation with the experts became a valuable resource for improving the quality of this decision process.

For the first time, A/R projects have been modeled in a comprehensive way through decision criteria that reflect multiple interests using a non-compensatory multicriteria method. The ELECTRE TRI model was used for assessing synergies at the project level, and has been a useful tool to quantify the performance of $\mathrm{A} / \mathrm{R}$ projects into three categories (synergistic, reasonably synergistic, and not synergistic).

Acknowledgments This article was developed in the framework of a Ph.D. in Forest Ecology at Tuscia University (Viterbo, Italy) and supported by the Ministry for the Environment, Land and Sea from Italy.

Open Access This article is distributed under the terms of the Creative Commons Attribution Noncommercial License which permits any noncommercial use, distribution, and reproduction in any medium, provided the original author(s) and source are credited.

\section{References}

Andre, S. (2007). Evaluation of environmental performances for an industrial site: A decision aiding methodology for facilitating the dialogue between stakeholders. Paper presented at the 22nd European Conference on Operational Research, Prague.

Appanah, S. (2003). Restoration of degraded forests as opportunities for development. Paper presented at the International Conference bringing back the forests Policies and Practices for Degraded Lands and Forests, Kuala Lumpur.

Arondel, C., \& Girardin, P. (2000). Sorting cropping systems on the basis of their impact on groundwater quality. European Journal of Operational Research, 127, 467-482.

Barbier, E. B., \& Markandya, A. (1990). The conditions for achieving environmentally sustainable growth. European Economic Review, 34, 659-669.

Barker, T., Bashmakov, I., Bernstein, L., Bogner, J. E., Bosch, P. R., Dave, R., et al. (2007). Technical summary. In B. Metz, O. R. Davidson, P. R. Bosch, R. Dave, \& L. A. Meyer (Eds.), Climate change 2007: Mitigation. Contribution of Working group III to the Fourth Assessment Report of the Intergovernmental Panel on Climate Change. Cambridge, United Kingdom and New York, NY, USA: Cambridge University Press.

Bouyssou, D. (1990). Building criteria: A prerequisite for MCDA. In Bana \& C. A. Costa (Ed.) Readings in multiple criteria decision aid (pp. 58-81). Heidelberg: Springer.

Bouyssou, D., Marchant, T., Pirlot, M., Tsoukiàs, A., \& Vincke, P. (2006). Evaluation and decision models with multiple criteria. Stepping stones for the analyst (English). In: International series in operations research \& management science (Vol. 86, 445 pp.). New York: Springer. 
Caparrós, A., \& Jacquemont, F. (2003). Conflicts between biodiversity and carbon sequestration programs: Economic and legal implications. Ecological Economics, 46, 143-157.

Cóndor, R. D. (2008). Multicriteria decision framework: Assessing synergies among the Rio Conventions at forestry project level. Dissertation, Università degli Studi della Tuscia.

Cóndor, R. D., Scarelli, A., \& Valentini, R. (2009). L'approccio multicriteri come strumento di supporto decisionale in ambito forestale. Forest@ Rivista di Selvicoltura ed Ecologia Forestale, 6(1), 161-172. doi:10.3832/efor0579-006.

Corbera, E., Kosoy, N., \& Martinez Tuna, M. (2007). Equity implications of marketing ecosystem services in protected areas and rural communities: Case studies from Meso-America. Global Environmental Change, 17, 365-380.

Dietz, S., \& Neumayer, E. (2007). Weak and strong sustainability in the SEEA: Concepts and measurement. Ecological Economics, 61, 617-626.

Figueira, J., Mousseau, V., \& Roy, B. (2005). ELECTRE methods. In J. Figueira, S. Greco, \& M. Ehrgott (Eds.), Multiple criteria decision analysis: State of the art survey (pp. 133-162). New York: Springer. http://www.diazdesantos.es/libros/figueiraj-multiple-criteria-decision-analysis-state-of-the-art-surveysL0010572110940.html

Global Environmental Facility-GEF. (2004). A conceptual design tool for exploiting interlinkages between the focal areas of the GEF. A report focusing on the needs of the Global Environment Facility. Scientific and Technical Advisory Panel of the GEF: Washington DC. Retrieved November 2007, from http://www.clacc.net/Documents/report/STAP\%20report.pdf.

Guitouni, A., \& Martel, J. M. (1998). Tentative guidelines to help choosing an appropriate MCDA method. European Journal of Operational Research, 109, 501-521.

Halsnæs, K., \& Markandya, A. (2002). The CDM and sustainable development: Case studies from Brazil and India. In A. Markandya \& K. Halsnæs (Eds.), Climate change and sustainable development. Prospects for developing countries (pp. 247-283). London: Earthscan.

Intergovernmental Panel on Climate Change-IPCC. (2002). Climate change and biodiversity. Intergovernmental Panel on Climate Change, Technical Paper.

International Union for Conservation of Nature-IUCN. (2005). NCSA as a mechanism to achieve synergies among Rio Conventions by Bhujang Dharmaji. BIOLOG Newsletter of the Regional Biodiversity Programme, Asia. Vol. 5 No 1 May 2005. Retrieved August 2006, from http://ncsa.undp.org/site_ documents/iuvn_biolog.pdf.

Kangas, J., \& Kangas, A. (2005). Multiple criteria decision support in forest management-the approach, methods applied, and experiences gained. Forest Ecology and Management, 207, 133-143.

Kangas, A., Kangas, J., \& Pykäläinen, J. (2001). Outranking methods as tools in strategic natural resources planning. Silva Fennica, 35(2), 215-227. Retrieved September 2007, from http://www.metla.fi/silva fennica/full/sf35/sf352215.pdf.

Klooster, D., \& Masera, O. (2000). Community forest management in Mexico: Carbon mitigation and biodiversity conservation through rural development. Global Environmental Change, 10, 259-272.

Kowalski, K., Stagl, S., Madlener, R., \& Omann, I. (2009). Sustainable energy futures: Methodological challenges in combining scenarios and participatory multi-criteria analysis. European Journal of Operational Research, 197, 1063-1074.

Madlener, R., Henggeler Antunes, C., \& Dias, L. C. (2009). Assessing the performance of biogas plants with multi-criteria and data envelopment analysis. European Journal of Operational Research, 197, 10841094.

Martinez-Alier, J., Munda, G., \& O’Neill, J. (1998). Weak comparability of values as a foundation for ecological economics. Ecological Economics, 26, 277-286.

Masera, O. R., Ceron, A. D., \& Ordonez, A. (2001). Forestry mitigation options for Mexico: Finding synergies between national sustainable development priorities and global concerns. Mitigation and adaptation strategies for climate change. Mitigation and Adaptation Strategies for Global Change, 6 , 291-312.

Millennium Ecosystem Assessment-MA. (2005). Ecosystems and human well-being: Desertification synthesis. Washington, DC: Island Press.

Mousseau, V., Figueira, J., Dias, L., Gomes da Silva, C., \& Clímaco, J. (2003). Resolving inconsistencies among constraints on the parameters of an MCDA model. European Journal of Operational Research, 147, 72-93.

Mousseau, V., \& Slowinski, R. (1998). Inferring an ELECTRE TRI model from assignment examples. Journal of Global Optimization, 12, 157-174.

Mousseau, V., Slowinski, R., \& Zielniewicz, P. (1999). ELECTRE TRI 2.0a Methodological guide and user's documentation. Document LAMSADE no.111, Université de Paris-Dauphine. 
Mousseau, V., Slowinski, R., \& Zielniewicz, P. (2000). A user-oriented implementation of the ELECTRETRI method integrating preference elicitation support. Computers \& Operations Research, 27, 757777.

Munda, G. (1997). Environmental economics, ecological economics and the concept of sustainable development. Environmental Values, 6(2), 213-233.

Munda, G. (2005). Multiple criteria decision analysis and sustainable development. In J. Figueira, S. Greco, \& M. Ehrgott (Eds.), Multiple criteria decision analysis: State of the art surveys (pp. 954-958). New York: Springer.

Nelson, K. C., \& de Jong, B. H. J. (2003). Making global initiatives local realities: Carbon mitigation projects in Chiapas, Mexico. Global Environmental Change, 13, 19-30.

Norese, M. F., \& Viale, S. (2002). A multi-profile sorting procedure and its use in the public administration. European Journal of Operational Research, 138(2), 365-379.

Olsen, K. H. (2007). The clean development mechanism's contribution to sustinable development: A review of the literature. Climatic Change, 84, 59-73.

Olsen, K. H., \& Fenhann, J. (2008). Sustainable development benefits of clean development mechanisms projects. A new methodology for sustainability assessment based on text analysis of the project design documents submitted for validation. Energy Policy, 36, 2819-2830.

Rennings, K., \& Hohmeyer, O. (1997). Linking weak and strong sustainability indicators: The case of global warming. Discussion paper No. 97-11E. Zentrum für Eurpaische Wirtschaftsforschung (ZEW)/ Center for European Economic Research. Retrieved July 2009, from http://opus.zbw-kiel.de/volltexte/2008/ 7132/pdf/dp1197.pdf.

Rousval, B. (2005). Aide multicritere a l'evaluation de l'impact des transports sur l'environnement. Dissertation, Lamsade Université Paris IX Dauphine.

Roy, B. (2005). Paradigms and challenges. In J. Figueira, S. Greco, \& M. Ehrgott (Eds.), Multiple criteria decision analysis: State of the art surveys (pp. 3-24). New York: Springer.

Roy, B., \& Bouyssou, D. (1993). Aide multicritère à la décision: Mèthodes et cas. Paris: Economica, Collection Gestion.

Sell, J., Koellner, T., Weber, O., Pedroni, L., \& Scholz, R. W. (2006). Decision criteria of European and Latin American market actors for tropical forestry projects providing environmental services. Ecological Economics, 58, 17-36.

Siskos, Y., Grigoroudis, E., Krassadaki, E., \& Matsatsinis, N. (2007). A multicriteria accreditation system for information technology skills and qualifications. European Journal of Operational Research, 182, $867-885$.

Smith, J., \& Scherr, S. J. (2002). Forest carbon and local livelihoods: Assessment of opportunities and policy recommendations. Center for International Forestry Research: Indonesia. Retrieved September 2006, from http://www.cifor.cgiar.org/publications/pdf_files/OccPapers/OP-037.pdf.

Srinivasa Raju, K., Duckstein, L., \& Arondel, C. (2000). Multicriterion analysis for sustainable water resources planning: A case study in Spain. Water Resources Management, 14, 435-456.

Stamelos, I., \& Tsoukiàs, A. (2003). Software evaluation problem situations. European Journal of Operational Research, 145, 273-286.

Sutter, C., \& Parreño, J. C. (2007). Does the current clean development mechanism (CDM) deliver its sustainable development claim? An analysis of officially registered CDM projects. Climatic Change, 84, 75-90.

Totten, M., Panda, S. I., \& Janson-Smith, T. (2003). Biodiversity, climate, and the kyoto protocol: Risks and opportunities. Frontiers in Ecology and the Environment, 1(5), 262-270. Retrieved August 2006, from http://www.jstor.org/pss/3868014.

Tsoukiàs, A. (2007). On the concept of decision aiding process: An operational perspective. Annals of Operations Research, 54, 3-27.

Umweltbundesamt-UBA. (2001). Requirements of climate protection with regards to the quality of ecosystems: Use of synergies between the framework convention of climate change and the convention on biological diversity. Prepared by A. Herold, U. Eberle, Ch. Ploetz and S. Scholz. German Federal Environmental Agency, Berlin: Germany. Retrieved August 2006, from www.biodiv-chm.de/ Documents/1057778062/download.

Umweltbundesamt-UBA. (2004a). Integration of biodiversity concerns in climate change. A toolkit. Developed by Keya Choudhury, Cornelia Dziedzioch, Andreas Häusler and Christiane Ploetz. German Federal Environmental Agency, Berlin: Germany. Retrieved September 2006, from http://www. umweltdaten.de/medien-e/biodiv.pdf.

Umweltbundesamt-UBA. (2004b). Suitable instruments for integrating biodiversity considerations in climate change mitigation activities, particularly in the land use and energy sector. Prepared by K. Choudhury, C. Dziedzioch, A. Häusler and C. Ploetz. German Federal Environmental Agency, 
Berlin: Germany. Retrieved September 2006, from http://www.umweltdaten.de/publikationen/fpdf-1/ 2788.pdf.

United Nations Convention to Combat Desertification/Convention on Biological Diversity-UNCCD/CBD. (2004). Workshop on Forests and Forest Ecosystems: Promoting synergy in the implementation of the three Rio conventions, Final Report, 5-7 April 2004, Viterbo, Italy.

United Nations Environment Programme/Convention on Biological Diversity-UNEP/CBD. (2004). Identifying and promoting synergies through forests and forests ecosystems. Note by the Executive Secretariat. A background paper prepared by Robert Nasi, Ken MacDicken, Center for International Forestry Research (CIFOR) (UNEP/CBD/WS-For-Syn/INF/1; 20 March 2004).

United Nations Environment Programme/Convention on Biological Diversity-UNEP/CBD. (2005). Report of the Subsidiary Body on Scientific, Technical and Technological Advice on the work of its Eleventh Meeting (UNEP/CBD/COP/8/3; 19 December 2005).

United Nations Environment Programme/Convention on Biological Diversity-UNEP/CBD. (2007). Biodiversity and Climate Change. Proposal from the Executive Secretary on options for mutually supportive activities for the secretariats of the Rio conventions, and options for parties and relevant organizations. Note by the Executive Secretary (UNEP/CBD/SBSTTA/13/7; 5 November 2007).

United Nations Framework Convention on Climate Change-UNFCCC. (2002). Cooperation with relevant international organizations. Cross-cutting thematic areas and activities under the United Nations Convention to Combat Desertification, Convention on Biological Diversity and United Nations Framework Convention on Climate Change. Note by the secretariat (FCCC/SBSTA/2002/INF.16; 11 October 2002).

United Nations Framework Convention on Climate Change-UNFCCC. (2004). Options for enhanced cooperation among the three Rio Conventions. Note by the secretariat (FCCC/SBSTA/2004/INF.19; 2 November 2004).

United Nations University Institute of Advanced Studies-UNU-IAS. (2004). UNU-IAS Report. Interlinkages approach for wetland management: The case of the pantanal wetland, November 2004, $28 \mathrm{pp}$.

Velasquez, J., Piest, U., \& Mougeot, J. (2002). Pacific Island Countries case study. Inter-linkages: Synergies and coordination among multilateral environmental agreements. Tokyo, Japan: United Nations University.

Vincke, P. (1992). Multicriteria decision aid. UK: West Sussex.

World Bank. (2005). Social analysis guidelines in natural resource management. Incorporating social dimensions in to Bank-supported projects. Washington, DC: Social Development Department, World Bank.

Yu, W. (1992). Aide multicritère à la décision dans le cadre de la problématique du tri: Méthodes et applications. Dissertation, Université Paris-Dauphine. 